\title{
No pretense to honesty: County government corruption in Mississippi
}

\author{
GÖKHAN R. KARAHAN, ${ }^{\dagger}$ LAURA RAZZOLINI ${ }^{\ddagger}$ AND WILLIAM F. SHUGHART II ${ }^{\ddagger}$ \\ ${ }^{\dagger}$ Department of Economics and Finance, Nicholls State University, Thibodaux, LA 70310 USA \\ ${ }^{\ddagger}$ Department of Economics, University of Mississippi, P. O. Box 1848, University, MS 38677- \\ 1848 USA
}

January 2004

Please do not quote without permission

\begin{abstract}
This paper explores the determinants of governmental corruption exploiting a unique dataset generated by an FBI investigation of county purchasing activities that ultimately led to the conviction of 55 of Mississippi's 410 county supervisors, one county road foreman, two state highway commissioners and 13 vendors on bribery, extortion and other felony charges. Evidence is reported that corruption occurs more frequently in rural counties where voter-taxpayers have fewer years of schooling. Corruption is also more likely in counties where supervisors are paid more, ceteris paribus, casting doubt on the proposition that efficiency wages purchase honest public officials.
\end{abstract}

JEL Keywords: corruption; rent seeking; county governments

\footnotetext{
* We are indebted to James Crockett for generously granting us early access to extracts from his since-published book manuscript. We benefited from discussions with Robert Tollison and from the comments of Hilary Shughart, attendees at the 2002 and 2003 meetings of the Southern Economic Association and the 2003 meetings of the Public Choice Society. Among the latter group, especially helpful suggestions were offered by Lee Coppock, Arthur Denzau, Fred McChesney, Michael Munger and Paul Pecorino. As is customary, however, we take full responsibility for any errors herein.
} 


\section{No pretense to honesty: County government corruption in Mississippi}

Only if one looks at the fine structure of political and economic systems can one go beyond a showing that corruption is harmful to an understanding of the way it operates in different contexts.... We need more systematic knowledge of just how corruption and self-dealing affect the operation of government programs and private markets. (Rose-Ackerman, 1999: 4)

\section{Introduction}

Each of Mississippi's 82 counties is managed by five supervisors, who are elected to concurrent four-year terms and are responsible for administering all county governmental functions except the public schools. ${ }^{1}$ Owing to this division of public policymaking labor, as a practical matter Mississippi's boards of supervisors spend most of their time and budgetary resources building and maintaining county roads and bridges.

Prior to 1988 , nearly every county in Mississippi operated under a governance system called the beat system. ${ }^{2}$ In that system, counties are partitioned geographically into five separate districts or "beats." After dividing the county's road budget into shares that are either equal or proportional to total county road mileages, each supervisor is independently responsible for establishing and executing spending priorities within his or her own beat: "under the beat system, the board of supervisors performed both the legislative and executive functions of government. It levied taxes and approved each district's road budget, while individual supervisors directed the day-to-day roadwork in their beats" (Crocket, 2003: 10). This decentralized method of governance afforded individual supervisors direct control - and considerable discretion - over

\footnotetext{
${ }^{1}$ Mississippi's county public school systems fall under the separate administrative jurisdiction of elected county school boards.

${ }^{2}$ The two exceptions were Neshoba County, whose supervisors voted unanimously on July 2, 1984, to switch from the beat to the unit system (the transition was completed on September 1, 1986), and Coahoma County, where, according to Crockett (2003: 231), "the unit system has been in operation more than 55 years...." The unit system is described in more detail below (see section III.D.).
} 
the allocation of county funds and county resources, such as labor, materials and supplies, and cranes, graders, trucks and other capital equipment.

Evidence that supervisory discretion had become a source of personal gain came to light in Operation Pretense, a high-profile federal investigation of Mississippi's county governments that ran from March 1984 to sometime in late $1987 .{ }^{3}$ The investigation was launched two years after the Reverend John Burgess, a Pentecostal minister who owned a building supply business in Carthage, Mississippi, a town in centrally located Leake County, first contacted the local office of the Federal Bureau of Investigation. He told federal agents in 1982 that he had learned, after investing in Polk Concrete, a pipe manufacturing company just south of Jackson, that the company's sales representatives could not do business with some counties unless they kicked back 10 percent of the purchase price to supervisors (ibid.: 4 ). ${ }^{4}$ Burgess subsequently agreed to open an FBI front operation, named Mid-State Pipe Company, next to his business in Carthage, and allow federal agents to pose as sales representatives of Mid-State, providing cover for a broad investigation of county government purchasing activities (ibid.: 5).

Operation Pretense exposed a plethora of corrupt practices, including bribery, extortion, mail fraud, bid-rigging, accepting kickbacks from suppliers and "busting" county invoices, a scheme whereby supervisors authorized payment for supplies never delivered and then split the overcharge with vendors. Fifty-five supervisors in 26 Mississippi counties, one county road foreman, two state highway commissioners and 13 vendors eventually were convicted on one or more felony counts. Only one of the seven supervisors whose cases went to trial was found

\footnotetext{
${ }^{3}$ The first indictments were handed down on Friday the $13^{\text {th }}$ of February 1987 (Crockett, 2003: 3).

${ }^{4}$ Bribes equal to ten percent of the value of the benefits conferred seem to be something of an iron law of public corruption. In her summary of the relevant literature, Rose-Ackerman (1999: 11, 19 \& 28) reports "commissions" of that magnitude being paid for import licenses in the Philippines, for reductions in taxes owed by property owners in New York City, and for the award of international construction contracts in Paraguay. Also see Atkinson, Couch and Shughart (1992).
} 
innocent; one supervisor was found mentally incompetent to stand trial and another died while under indictment and awaiting the disposition of his case. A guilty verdict was likewise handed down by the jury empanelled to hear the case of the sole vendor who contested the charges filed against him. The remaining defendants, including all of the supervisors, pled guilty to various felonies in federal or state court; all were ordered to pay fines, make restitution of ill-gotten gains, or both, and received prison sentences of up to 10 years. ${ }^{5}$

The purpose of this paper is to study the underlying causes of the unlawful behavior that led to the filing of corruption charges against one-eighth of Mississippi's county supervisors. Using a unique county-level dataset, we find that governments tend to be more corrupt in rural and less well-educated counties. We also find that a county's supervisors were more likely to engage in corruption when corruption existed in neighboring counties. Finally, the evidence suggests that, other things being the same, corruption was more prevalent in counties where supervisors were paid more.

The paper is organized as follows. Section II summarizes our data and reports descriptive statistics on corrupt and non-corrupt counties in the State of Mississippi. Empirical models and estimation results are presented in Section III. Supplementary evidence also presented there provides additional insights into the determinants of public corruption. Section IV concludes.

\section{The extent of county government corruption in the State of Mississippi}

Figure 1 shows the 26 Mississippi counties in which one or more supervisors were convicted on charges brought to light by Operation Pretense. Although indictments were eventually handed down against supervisors in only about a third of the state's 82 counties, there is reason to

\footnotetext{
${ }^{5}$ See Crockett (2003: 301-7) for a list containing the identities of the individuals charged under Operation Pretense and the disposition of their cases. The charges against many of the indicted vendors and public officials subsequently were reduced - and in a few instances dismissed - in return for cooperation in the FBI's investigation.
} 
Figure 1. Corrupt and non-corrupt Mississippi counties

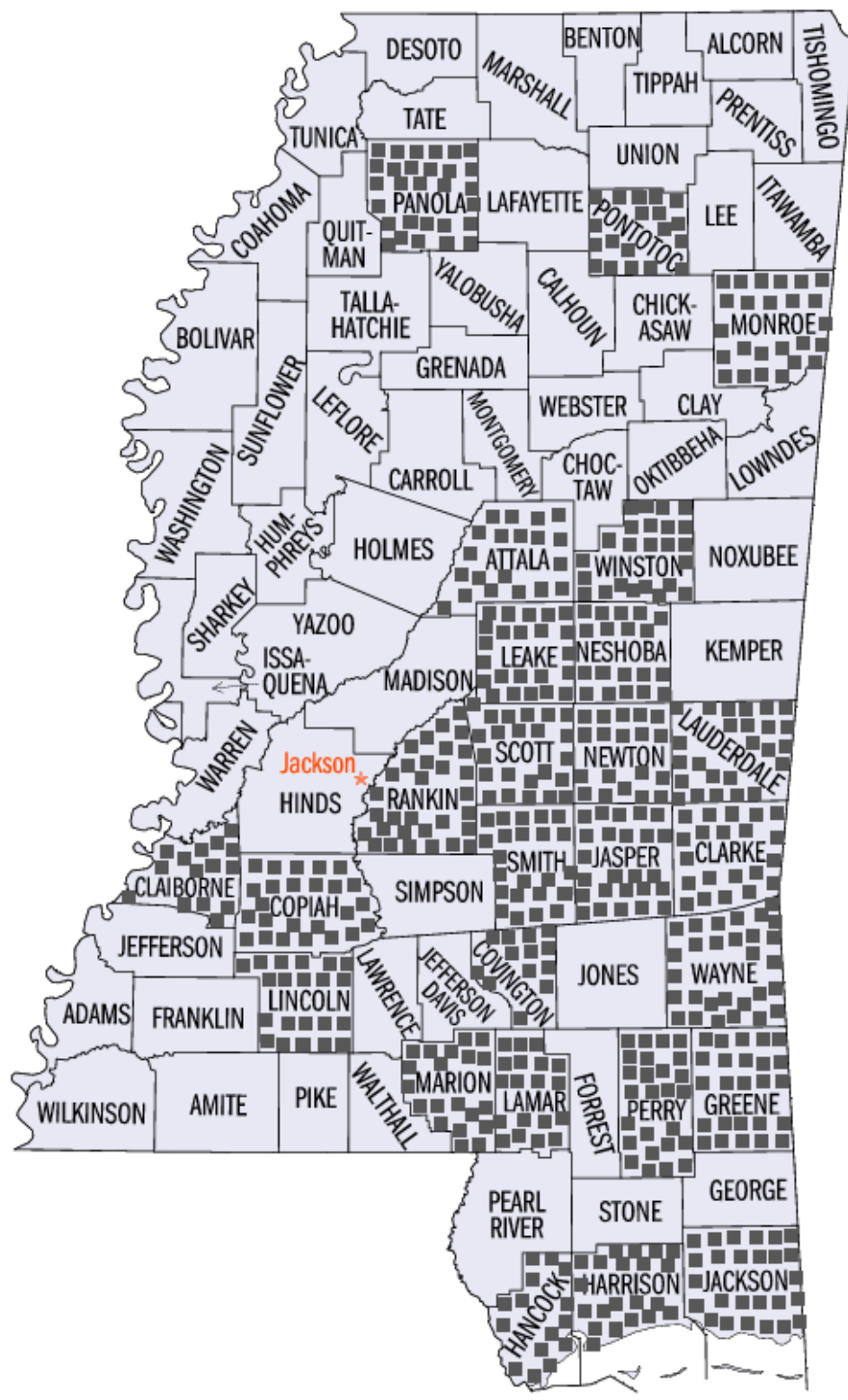

Note: Square dots indicate counties where one or more supervisors were convicted of corruption on charges brought under Operation Pretense. 
believe that the federal investigation cast a wide net. In the early stages of Operation Pretense, Jerry King, one of the federal undercover agents, met with Ray Davis, a vendor who began cooperating with the FBI in June 1986. At that meeting, "King took the list of members of the Mississippi Association of Supervisors and went over it with Davis, as they told each other which supervisors they had paid kickbacks" (ibid.: 9). In an interview aired in May 1987 on 60 Minutes, Davis said that "he had made kickbacks to twenty-five to thirty-five county supervisors all over the state" (ibid.: 278; emphasis added). Subsequently, other vendors and supervisors came forward to supply information that would aid in identifying corrupt county officials.

Such corroborating evidence was necessary to avoid the possibility that defendants could claim entrapment: "as a general rule, federal prosecutors will not charge anyone with a crime based solely on the testimony of an FBI agent or someone who is cooperating with an investigation as part of a plea bargain" (ibid.: 12). This legal requirement of "predication" consequently narrowed the investigation's scope to counties in which there was reason to believe beforehand that a supervisor had engaged in corrupt practices or was predisposed to do so. While we do not know how many of Mississippi’ counties were in fact targeted by Operation Pretense, we do know that investigations were carried out in more than the 26 jurisdictions in which convictions eventually were obtained. The evidence gathered by FBI agents against supervisors in George and Marshall Counties, for example, apparently was insufficient for charges to be filed (ibid.). ${ }^{6}$ And in Lafayette County, according to a 2003 supervisor candidate, Operation Pretense indictments against two supervisors may have been quashed as a result of political pressure on the local U.S. Attorney. ${ }^{7}$ Hence, the federal investigation of county corruption was carried out

\footnotetext{
${ }^{6}$ The treasuries of these two counties nevertheless received refunds of monies collected by FBI agents in fraudulent transactions with supervisors. All told, 19 Mississippi counties received \$53,000 in such refunds (Crockett, 2003: 12).

${ }^{7}$ Personal interview with the third-named author.
} 
statewide, and was limited only to the extent that documented evidence of a propensity to corruption had to be in hand before undercover agents attempted to "sting" individual public officials by secretly recording offers or acceptances of unlawful payoffs.

Table 1 classifies the 26 counties in which Operation Pretense convictions were obtained according to the number of supervisors found guilty at trial or entering guilty pleas in federal court. The table shows the mean fines assessed, restitutions ordered and jail sentences imposed per guilty official.

Table 1. Fines, restitutions and jail sentences

\begin{tabular}{|c|c|r|r|r|}
\hline $\begin{array}{c}\text { Number of } \\
\text { corrupt } \\
\text { supervisors }\end{array}$ & $\begin{array}{c}\text { Number } \\
\text { of } \\
\text { counties }\end{array}$ & $\begin{array}{c}\text { Average fine } \\
\text { per supervisor }\end{array}$ & $\begin{array}{c}\text { Average } \\
\text { restitution per } \\
\text { supervisor }\end{array}$ & $\begin{array}{c}\text { Average sentence } \\
\text { per supervisor } \\
\text { (months) }\end{array}$ \\
\hline 1 & 10 & $\$ 3,600$ & $\$ 2,375$ & 37 \\
\hline 2 & 7 & 6,143 & 2,135 & 43 \\
\hline 3 & 7 & 4,833 & 1,198 & 152 \\
\hline 4 & 1 & 2,250 & 926 & 114 \\
\hline 5 & 1 & 1,700 & 0 & \\
\hline
\end{tabular}

Two points about these data are worth emphasizing. First, Table 1 shows the penalties actually imposed on the 54 Mississippi county supervisors who were convicted or pled guilty to corruption. ${ }^{8}$ Except for six of the seven individuals who contested the charges against them and subsequently were found guilty at trial, all of these penalties resulted from plea bargains with U.S. Attorneys. As such, the fines, restitutions and jail sentences ordered by the courts emerged from deals in which the government's lawyers accepted reductions in the original number of felony counts in return for guilty pleas that avoided the costs of litigation. Penalties were reduced

\footnotetext{
${ }^{8}$ As mentioned earlier, one of the 57 indicted supervisors was found mentally incompetent to stand trial (Perry County), one supervisor (Claiborne County) was found not guilty of all charges and another (Newton County) pled guilty but died while awaiting the final disposition of his case. The indictment against the deceased supervisor subsequently was dismissed. See Crockett (2003: 17, 66 \& 196). The number of supervisors indicted in each of the 26 Mississippi counties is listed in the appendix.
} 
most in plea bargains with supervisors who agreed to cooperate with the FBI's investigation and the most cooperative supervisors often were those against whom the most serious charges initially had been filed. Across all 26 counties, plea bargaining produced dramatic decreases in the penalties for corruption, lessening the mean fine per guilty supervisor from $\$ 527,259$ to $\$ 4,463$ and shortening prison sentences considerably. Deals with prosecutors resulted in much smaller reductions in restitution amounts - from $\$ 2,252$ to $\$ 1,532$, on the average. ${ }^{9}$

Second, the court-ordered restitutions tend to be small in dollar value. That is because most of the convicted supervisors took advantage of state procurement laws which permitted them to "make purchases of up to $\$ 500$ without competitive bids." While "purchases between $\$ 500$ and $\$ 2,500$ required two bids or quotes,... the supervisors did not have to advertise for bids. Advertising for competitive bids was required for purchases costing more than $\$ 2,500$ " (ibid.: 10). These statutory requirements frequently were evaded by splitting invoices for large purchases into two or more small purchase orders, although that practice was itself illegal. Hence, computed as they normally were at 10 percent of the invoice, the kickbacks supervisors illegally accepted on any one transaction rarely exceeded \$200.

\section{Empirical models of corruption}

Micro-level studies of governmental corruption are few in number. Most prior work in this area involves cross-country comparisons and tends to focus on the consequences - as opposed to the causes - of rent-seeking, corruption, or both (e.g., Tullock, 1967; Krueger, 1974; Bhagwati, 1982; Tollison, 1982; Elliot, 1997; Tresman, 2000). Mauro (1997), who studied corruption's

\footnotetext{
${ }^{9}$ Restitutions were determined by the amounts supervisors feloniously had accepted in kickbacks on transactions with vendors. The monies at issue were ordered paid to their respective county governments. Under Mississippi law, it is not illegal for public officials to accept gifts, provided that the amounts received are declared and turned over to the public treasury (Crockett, 2003: 82).
} 
negative impacts on private capital formation and rates of economic growth, is a representative contribution to this literature, which is helpfully summarized in Barnhan (1997). ${ }^{10}$

Ades and Di Tella (1999), on the other hand, attempted to explain the determinants of public corruption. Per capita GDP, schooling, lack of political rights, and variables measuring the levels of competition and regulation were analyzed in a number of multivariate models. Using data from the 1990s, Ades and Di Tella found that corruption is encouraged by the existence of economic rents, but that education and per capita GDP do not play significant explanatory roles. When they applied their model to 1980s data, by contrast, corruption was negatively and significantly related to the level of income per capita and educational attainment in a country.

Frechette (2003) criticizes the existing empirical work on corruption for failing to take account of the possibility that corruption and national income are determined simultaneously. Applying an instrumental-variables technique to the problem, Frechette finds that corruption and GDP are positively related and that rents foster corruption, ceteris paribus.

Given that economists have only recently turned their attention to the study of corruption, it should come as no surprise that consensus has not yet been reached on its underlying causes. Despite the rapid expansion of the corruption literature (for recent surveys, see Jain, 2001 and Aidt, 2003), many important questions remain unanswered, as this paper's epigraph suggests. In what follows, we rise to Rose-Ackerman's challenge.

\section{A. Data, models and estimation methodology}

Our dataset combines information from Crockett (2003), the Mississippi Statistical Abstract (Office of External Affairs, various years), the Census Bureau's County and City Data Book

\footnotetext{
${ }^{10}$ More recently, Schneider and Enste (2000: 90-91) suggest that the growth-retarding effects of corruption operate by shifting economic activities to the shadow economy.
} 
(U.S. Department of Commerce, various years) and the publications of the Mississippi State Highway Department $(1982,1993)$. The first of these sources identifies the county supervisors who were indicted in the course of Operation Pretense and reports on the disposition of their cases. $^{11}$

Our dependent variable is unique. Unlike many previous studies which have used indices of "perceived corruption," often based on evidence gathered in surveys, the results of Operation Pretense allow us to observe the actual number of public officials convicted of corruption in each of Mississippi’s 82 counties. Our empirical model is specified as follows:

\section{NUMBER of CORRUPT SUPERVISORS $=f($ SUPERVISOR SALARY, BORDER, EDUCATION, POPULATION DENSITY, ROAD MILES).}

The ordered dependent variable assumes a value of 5 if all of a county's supervisors were convicted of corruption, a value of 4 if four of five supervisors were convicted, and so on. The dependent variable is set equal to 0 if none of a county's supervisors were caught in Operation Pretense's net. The explanatory variables are defined below. The observations on each of these were recorded at the county level and cover the years between 1980 and 1982, a period prior to the launching of the federal investigation in March 1984.

SUPERVISOR SALARY. The salaries of Mississippi’s county supervisors are fixed by law and based on a county's total assessed value. Given the assessed value, the Mississippi legislature determines, county by county, the maximum compensation members of the state's 82 boards of supervisors are authorized to earn annually. That figure is known as a county's “code income," which establishes an upper bound on supervisors' pay; all five of a county's

\footnotetext{
${ }^{11}$ Prior to the publication of Crockett's (2003) book, we had constructed a list of indicted supervisors by consulting stories published in the Jackson, Miss., Clarion-Ledger, 15 February 1987, p. 1A; 9 November 1988, p. 1A; and 13 September 1987, p. 1A. A Freedom of Information Act request submitted by the authors to the Jackson Office of the U.S. Attorney generated an incomplete list of the fines and restitutions ordered in Operation Pretense-related cases; it did, however, identify the 26 counties in which felony convictions were obtained.
} 
supervisors receive the same amount. ${ }^{12}$ Unfortunately, we have not been able to obtain information on supervisors' actual salaries, which may be less than code income in some jurisdictions. ${ }^{13}$ Since salaries depend on the assessed value of counties and are set by the Mississippi legislature, it seems reasonable to treat supervisors' pay as being exogenous to our regression model.

Be that as it may, the economic theory of crime and punishment (Becker, 1968; Becker and Stigler, 1974) suggests that, holding the probability of detection constant, public officials are more likely to engage in corrupt practices when the income earned from public service is low. Put differently, high pay deters corruption in an efficiency wage sense because officials fear the loss of a secure income stream if malfeasance is detected and they lose their jobs. Goel and Nelson (1998) and Di Tella and Schargrodsky (2003) report evidence consistent with the efficiency-wage story. ${ }^{14}$ On the other hand, time series results from 25 countries lead Van Rijckeghen and Weder (2001) to reject the hypothesis that higher relative wages lead to lower levels of public corruption, as measured by a corruption index. ${ }^{15}$ The implication is that, if

\footnotetext{
${ }^{12}$ See Mississippi Code of $1972 \S 25-3-13$ for authorized county supervisor salaries. For the purposes of this study, we have used the 1980 grand assessed value of each county to determine supervisors' salaries based on the numbers suggested by the Mississippi Code $§$ 25-3-13 (House Bill No 422, approved May 23, 1980, effective October 1, 1980). Paul Smith of the Mississippi State Tax Commission provided us with the 1980 grand assessed values of Mississippi's 82 counties.

${ }^{13}$ Mississippi law requires a simple majority of a county's supervisors to vote affirmatively to accept a legislatively authorized pay increase and to record the results of such voting on the board's minutes.

${ }^{14}$ In particular, using 1983-87 data from the U.S. states, Goel and Nelson find that the conviction rates of public employees for abuses of office are significantly lower where the average wage of state and local government employees is higher relative to state personal income. On the other hand, they also report evidence of a positive and significant relationship between corruption and government size, as measured by real total state and local government expenditures per capita. Since one would expect the salaries of public employees to be higher in biggovernment states, as a test of the Becker-Stigler model these empirical results are ambiguous at best. Di Tella and Schargrodsky (2003) find that corruption and wages are negatively correlated in the presence of proper auditing and control. For additional applications of the Becker-Stigler model to governmental corruption, see Basu, Bhattacharya and Mishra (1992), Besley and McLaren (1993) and Mookherjee and Png (1995).

${ }^{15}$ In the same study, using a cross-sectional methodology, Van Rijckeghen and Weder find a negative ceteris paribus relationship between relative pay (the ratio of civil service to manufacturing wages) and the corruption index.
} 
corrupt activities are highly remunerative, a high official salary may not be enough to deter misuses of public office. As Rose-Ackerman (1999: 78) puts it, high pay may simply increase the bribe an official demands in order to overcome the risks of losing what is now a desirable job. Officials may go from being "lean and mean" to being "fat and mean." The incidence of bribery may fall as fewer officials solicit or accept payoffs, but the size of each bribe increases.

In short, the data will have to tell us which effect dominated in Mississippi at the time of Operation Pretense. Other things being the same, was corruption more or less likely in counties where the salaries of supervisors were higher ${ }^{16}$

BORDER is an indicator variable assuming a value of 1 if a county borders a corrupt county; 0 if not. This variable is included to account for spatial autocorrelation and to test whether corrupt behavior in one county transfers to (or is imitated by) supervisors in neighboring counties. Figure 1 preliminarily suggests that this is so: of the 26 corrupt counties in Mississippi, 24 bordered one another; of the 56 non-corrupt counties, 36 bordered corrupt counties.

POPULATION DENSITY. A negative relationship between the population density of a county (observed here in 1980) and public corruption is hypothesized. That a priori algebraic sign is suggested by the logic of collective action (Olson, 1965), which implies that it is more costly for voter-taxpayers to monitor their elected public officials and to control corrupt activities in rural counties where the population is more dispersed geographically.

EDUCATION. The level of education in a county is measured as the percentage of the population (over 25 years of age) having 16 years or more education in 1980. Consistent with

\footnotetext{
${ }^{16}$ As recognized by Becker and Stigler (1974), Jain (2001) and Di Tella and Schargrodski (2003) emphasize that the relationship between corruption and wages depends, barring any simultaneity issues, on the level of control and audit. In other words, high salaries combined with a high level of legal and institutional scrutiny may lower the incidence of corruption, and, thus, confirm an efficiency-wage story. Mississippi offers evidence undercutting the hypothesis that the probability of detection matters: corruption among county supervisors continued long after it was known that Operation Pretense was underway: in the third year of the federal undercover investigation, when "many indictments had been returned and trials were taking place, supervisors were still asking for and taking payoffs." Indeed, "several supervisors continued their corrupt practices even after being indicted" (Crockett, 2003: 7).
} 
previous studies, as well as on the theory that a less educated citizenry is both less likely to be informed about their county supervisors and to vote, we posit a negative relationship between education and corruption.

ROAD MILES. As noted earlier, Mississippi’s supervisors spend most of their time and the lion's share of their budgetary resources building and maintaining county roads and bridges. Prior to 1993, the Mississippi State Highway Department classified roads into two main categories: rural versus urban. Interstate highways were classified as "Rural Interstate" and “Urban Interstate." We summed the 1982 mileages of all rural roads in a county (excluding the rural segments of interstate highways) to construct ROAD MILES. As US highways in the state were not then separately classified, this variable may either overstate or understate the true number of road miles under the jurisdiction of a county's supervisors.

Starting in 1993, however, the State Highway Department has maintained a reporting system that clearly segregates the mileages of the roads city and county governments are responsible for maintaining. We therefore present results below using two alternative proxies for county road miles. One proxy, ADJUSTED82, applies the 1993 percentage of road miles maintained by county governments (out of the total for that year) to estimate ROAD MILES in 1982. The other proxy, ROAD MILES93, is simply the actual mileages of county roads in 1993. All of these data were collected from Mississippi State Highway Department $(1982,1993)$. A priori reasoning suggests that counties with larger road mileages create more opportunities for supervisors to demand kickbacks on purchase orders, to solicit bribes or to engage in other corrupt practices. We therefore expect a positive sign on any of the mileage 
measures, a result indicating that the probability of corruption rises with the total number of county road miles. ${ }^{17}$

Table 2 reports descriptive statistics. The simple pair-wise comparisons presented there suggest that average supervisor salaries are higher in counties where one or more supervisors were convicted on corruption charges. This is consistent with the results obtained by Van Rijckeghem and Weder (1997). Corrupt Mississippi counties also appear to have lower levels of education and higher population densities. ROAD MILES seems to be higher in the corrupt counties than in the non-corrupt counties. ${ }^{18}$ Whether these relationships hold in a multivariate context is the question we answer in the following section.

Table 2. Descriptive statistics

\begin{tabular}{|l|r|r|r|c|}
\hline $\begin{array}{c}\text { Non-corrupt } \\
(\mathbf{5 6} \text { counties) }\end{array}$ & $\begin{array}{c}\text { SUPERVISOR } \\
\text { SALARY } \\
\mathbf{( \$ )}\end{array}$ & $\begin{array}{c}\text { EDUCATION } \\
\mathbf{( \% )}\end{array}$ & $\begin{array}{c}\text { POPULATION } \\
\text { DENSITY }\end{array}$ & $\begin{array}{c}\text { ROAD } \\
\text { MILES }\end{array}$ \\
\hline Mean & 15,295 & 10.28 & 51.32 & 738.26 \\
\hline Standard deviation & 2,035 & 4.57 & 44.41 & 206.98 \\
\hline Minimum & 13,500 & 5.60 & 6.20 & 268.12 \\
\hline Maximum & 22,600 & 28.30 & 286.90 & 1359.03 \\
\hline $\begin{array}{c}\text { Corrupt } \\
(\mathbf{2 6} \text { counties) }\end{array}$ & $\begin{array}{c}\text { SUPERVISOR } \\
\text { SALARY } \\
\mathbf{( \$ )}\end{array}$ & $\begin{array}{c}\text { EDUCATION } \\
(\mathbf{\%})\end{array}$ & $\begin{array}{c}\text { POPULATION } \\
\text { DENSITY }\end{array}$ & $\begin{array}{c}\text { ROAD } \\
\text { MILES }\end{array}$ \\
\hline Mean & $\$ 16,081$ & 9.25 & 53.42 & 879.48 \\
\hline Standard deviation & 2,451 & 2.75 & 54.46 & 152.61 \\
\hline Minimum & 13,500 & 6.50 & 13.70 & 453.94 \\
\hline Maximum & 22,600 & 17.00 & 271.40 & 1172.56 \\
\hline
\end{tabular}

\footnotetext{
${ }^{17}$ It is possible that corruption and road miles are simultaneously determined. However, that possibility seems remote given that county road mileages have been declining over time in Mississippi owing, for example, to county land annexation by city governments.

${ }^{18}$ The same relationship holds for ADJUSTED82 (the means are 677 miles for corrupt counties and 587 miles for non-corrupt counties) and for ROAD MILES93: the corresponding means are 717.63 miles and 613.24 miles, respectively.
} 


\section{B. Empirical results}

Estimates of two empirical models are presented in Tables $3 \mathrm{a}$ and $3 \mathrm{~b}$. The first set of results is based on the cumulative (ordered) logit model described above; the second set of results is presented using a binary dependent variable taking a value of 1 if any supervisors were convicted in a county and set equal to 0 otherwise. ${ }^{19}$ The two regressions tell essentially the same story.

In particular, the likelihood of observing supervisor corruption is higher in counties where supervisors' salaries are higher. This finding is consistent with the hypothesis that high pay for public officials by itself is not enough to deter corruption when the extra income available from corrupt activities is also high. Of course, it is also possible that our model fails to include relevant personal characteristics of the supervisors who engaged in corruption. ${ }^{20}$

As expected, corruption is more likely in counties with lower education levels. It is also more likely in counties with lower population densities, but the estimated coefficient on that variable is not different from zero at standard levels of statistical significance. Moreover, it appears that corruption is contagious: BORDER is positive and significant, indicating that the existence of corruption in one county raises the likelihood of observing corruption in neighboring counties. It is also apparent that counties with more road miles tend to have more corruption. $^{21}$

\footnotetext{
${ }^{19}$ The cumulative logit model allows for different intercepts. In Table 3b, for example, Intercept-5, indicating counties where five supervisors were convicted of corruption, is the predicted log-odds ratio of being in the fivecorrupted-supervisors category rather than being in categories where four, three, two or one supervisors were convicted, when the values of the other independent variables are constrained to be zero (Allison, 1999: 134-42). The standard logit model in Table $3 \mathrm{~b}$ assumes a binary response where the dependent variable can take on two values: 1 for those counties having one or more corrupt supervisors and 0 otherwise.

${ }^{20}$ One possibility is a supervisor's length of service in office. This could go either way. Trudie Westmoreland of Perry County, the first Mississippi supervisor tried and convicted of Operation Pretense-related charges, argued in court that her inexperience - she was serving her first term - caused her unintentionally to accept kickbacks from suppliers. On the other hand, her fellow Perry County supervisor, Junie Mixon, who died while awaiting sentencing on corruption charges, had been in office for 19 years. See Crockett (2003: 15ff.).

${ }^{21}$ Similar results are obtained using the two alternatives to ROAD MILES described in the text above. The only material differences are that ADJUSTED82 enters with marginally less significance and that POPULATION
} 
Table 3a. The likelihood of observing corruption (cumulative logit model)

\begin{tabular}{|c|c|c|}
\hline Variable & $\begin{array}{c}\text { Coefficient } \\
\text { estimate }\end{array}$ & p-value \\
\hline Intercept-1 & -11.1188 & 0.0007 \\
\hline Intercept-2 & -12.0350 & 0.0003 \\
\hline Intercept-3 & -12.8735 & 0.0001 \\
\hline Intercept-4 & -14.5646 & $<.0001$ \\
\hline Intercept-5 & -15.2760 & $<.0001$ \\
\hline SUPERVISOR SALARY & 0.0005 & 0.0302 \\
\hline BORDER & 2.6360 & 0.0034 \\
\hline EDUCATION & -0.3239 & 0.0279 \\
\hline POPULATION DENSITY & -0.0135 & 0.2521 \\
\hline ROAD MILES & 0.0043 & 0.0096 \\
\hline \multicolumn{3}{|c|}{ Wald chi-square for overall significance: 0.0029} \\
\hline \multicolumn{3}{|c|}{ Percentage of correctly classified responses: 0.79} \\
\hline
\end{tabular}

Table $3 b$. The likelihood of observing corruption (binary logit model)

\begin{tabular}{|l|r|r|}
\hline \multicolumn{1}{|c|}{ Variable } & $\begin{array}{c}\text { Coefficient } \\
\text { estimate }\end{array}$ & \multicolumn{2}{c|}{ p-value } \\
\hline Intercept & -17.5431 & 0.0004 \\
\hline SUPERVISOR SALARY & 0.0011 & 0.0035 \\
\hline BORDER & 3.3288 & 0.0030 \\
\hline EDUCATION & -0.5356 & 0.0096 \\
\hline POPULATION DENSITY & -0.0138 & 0.1569 \\
\hline ROAD MILES & 0.0043 & 0.0239 \\
\hline
\end{tabular}

Wald chi-square for overall significance: 0.0105

Percentage of correctly classified responses: 0.87

DENSITY becomes significant (at the 10-percent level) when ROAD MILES93 is entered in the binary logit model. More specifically, when ADJUSTED82 replaces ROAD MILES, we observe the following p-values in the binary logit model: SUPERVISOR SALARY $=0.0027$, BORDER $=0.0033$, EDUCATION $=0.0079$, POPULATION DENSITY $=0.1866$ and ADJUSTED82 $=0.0962$. For the cumulative logit model, the p-values are: SUPERVISOR SALARY $=0.0162$, BORDER $=0.0042$, EDUCATION $=0.0224$, POPULATION DENSITY $=0.2388$ and ADJUSTED82 $=0.0519$. The following p-values are obtained for the binary logit model when ROAD MILES93 is entered: SUPERVISOR SALARY $=0.0035, \mathrm{BORDER}=0.0034, \mathrm{EDUCATION}=0.0084$, POPULATION DENSITY $=0.0633$ and ROAD MILES93 $=0.0302$. For the cumulative logit model, the p-values are SUPERVISOR SALARY $=0.0314$, BORDER $=0.0039$, EDUCATION $=0.0267$, POPULATION DENSITY $=$ 0.1032 and ROAD MILES93 = 0.0119 . 
In addition to providing support for the conjecture of Van Rijckeghem and Weder (1997), our finding of a positive relationship between corruption and pay is also consistent with the following interpretation. As noted earlier, the Mississippi Code determines the maximum allowable salaries of county supervisors. A given county's supervisors are nevertheless free to pay themselves less than the allowed maximum, an action they might take if they fear voter opposition to increasing their own incomes. In such cases, supervisors may have incentive to capture the difference under the table by accepting or extorting bribes from vendors. ${ }^{22}$ To test this possibility, we replaced SUPERVISOR SALARY in our two regression models by a new independent variable, defined as the difference between the supervisor's salary and the per capita income in a county. ${ }^{23}$ Without affecting the signs or significances of the other included explanatory variables (POPULATION DENSITY is the sole exception), the estimated coefficient on the new variable is positive and significant at a p-value of 0.0135 , providing some support for this conjecture.

We ran other models to see whether our results would change if we were to assume contrary to fact that a Newton County supervisor had not died while under indictment and a Perry County supervisor had not been declared mentally incompetent to stand trial. The results reported in Table 3 are unaffected by adding these two individuals to the sample of convicted public officials.

\section{Competition and corruption}

Across the 26 Mississippi counties in which supervisors were convicted of the unlawful practices brought to light by Operation Pretense, corruption involved as few as one and as many as five

\footnotetext{
22 "If public pay is very low, corruption is a survival strategy.... In these cases, officials are likely to take second jobs or accept payoffs as salary supplements" (Rose-Ackerman, 1999: 72).

${ }^{23}$ The mean per capita income in the 26 counties with one or more corrupt supervisors is $\$ 6,456$, with a standard deviation of $\$ 876$; the mean per capita income in the non-corrupt counties is $\$ 6,274$ (standard deviation $=\$ 1,119$ ).
} 
supervisors, with an overall mean of 2.08 individuals. The available empirical evidence affords an opportunity to test whether the level of governmental corruption is a function of the number of public officials who participated in breaking the law.

In extending the theory of oligopoly to corruption in the public sector, Shleifer and Vishny (1993) show that competition among a set of officials who have authority to grant similar favors tends to reduce the bribe any one of them can demand. ${ }^{24}$ This result follows from observing that, if one officeholder insists on a supranormal kickback, rational favor-seekers will respond by shifting their business to alternative officials who are willing to accept lower fees for service. On the other hand, when a single officer acts as gatekeeper, or two or more public employees having such authority are able successfully to collude, bribes approach monopoly profit-maximizing levels.

Because collusive agreements are cheaper to organize and to enforce the fewer the parties involved (Stigler, 1974), theory predicts less wealth extraction from vendors in counties where more of the supervisors engaged in the corrupt practices uncovered by Operation Pretense. Accordingly, we divided our sample of 26 Mississippi counties into the following two categories: 17 counties with a below-average level of corruption (one or two convicted supervisors) and nine counties where the level of corruption observed was above the average (three, four or five convicted supervisors). We then calculated the arithmetic means of the monetary penalties (fines and restitutions) imposed per guilty supervisor in the two subsamples. The results are reported in Table 4.

The available data suggest that corrupt behavior was less costly to vendors in counties where more of the supervisors were on the take. The restitutions ordered in the nine jurisdictions

\footnotetext{
${ }^{24}$ Rose-Ackerman (1978) apparently was the first scholar to suggest that corruption can be reduced by introducing competition at the level of the official receiving bribes.
} 
Table 4. Average fines and restitutions per supervisor grouped by numbers of guilty officials

\begin{tabular}{|l|r|r|}
\hline \multirow{2}{*}{$\begin{array}{c}\text { Monetary } \\
\text { penalties }\end{array}$} & \multicolumn{3}{|c|}{ Number of corrupt supervisors per county } \\
\cline { 2 - 3 } \multicolumn{1}{c|}{$\begin{array}{c}\text { One or } \text { wo } \\
(17 \text { counties })\end{array}$} & $\begin{array}{c}\text { Three or more } \\
(9 \text { counties })\end{array}$ \\
\hline Average fine & $\$ 5,083$ & $\$ 3,983$ \\
\hline Average restitution & 2,245 & 962 \\
\hline
\end{tabular}

Note: The mean number of guilty supervisors per county is $54 / 26=2.08$. The average code income in the 17 counties with one or two corrupt supervisors is $\$ 16,718$; it is $\$ 14,878$ in the nine counties with three or more corrupt supervisors.

where convictions were obtained against three or more supervisors were substantially smaller, on the average, than those ordered in counties where only one or two supervisors were found guilty of corruption. That result is consistent with the hypothesis that kickbacks were demanded less frequently from vendors in the more corrupt counties or, alternatively, represented smaller percentages of the dollar value of the unlawful transactions uncovered by Operation Pretense. ${ }^{25}$ Supervisors in counties where three or more convictions were obtained also paid smaller fines, on the average, reinforcing the conclusion that corruption in those jurisdictions was less egregious.

Additional insight into corruption is gained by comparing supervisors' salaries in these two groups of counties. In 1980, average supervisors' salaries were higher in the 17 counties where Operation Pretense produced the largest monetary recoveries per guilty supervisor. In particular, the mean annual income of supervisors in that sample of counties was $\$ 16,718$ in $1980 .^{26}$ During the same year, by contrast, supervisors earned salaries averaging $\$ 14,878$ per year in the nine counties where three or more of the officials were found to be corrupt and fines and restitutions were lower, ${ }^{27}$ a difference of $\$ 1,840$ or $11.69 \%$. To the extent that court-ordered

\footnotetext{
${ }^{25}$ Rose-Ackerman (1999: 55) observes that, by itself, "the right of recovery" of ill-gotten gains "is a weak deterrent to corrupt payoffs because the recovery is not multiplied by a factor that reflects the probability of detection."

${ }^{26}$ Supervisors' salaries in these 17 counties ranged from a low of $\$ 13,900$ (Perry), to a high of $\$ 22,600$ (Jackson).

${ }^{27}$ The salary range in these nine counties was $\$ 13,500$ (Greene County) to $\$ 16,500$ (Hancock County).
} 
restitutions are indicators of the level of bribery, we have some evidence that high pay reduces the number of officials who engage in unlawful behavior: among the 26 counties where at least one supervisor was corrupt, fewer supervisors were convicted where average salaries were higher. On the other hand, a high-paid official who becomes corrupt tends to demand larger bribes or demands them more often. "Officials ... go from being 'lean and mean' to being 'fat and mean'," as Rose-Ackerman (1999: 78) suggests.

Based as they are on small numbers, these results are far from definitive. The evidence at hand nevertheless indicates that competition between corrupt public officials tends to reduce the level of bribery and, moreover, that officials who are paid more extract bigger bribes. But to reiterate our earlier findings, Mississippi's county supervisors were more likely to have engaged in corruption where their salaries were higher, all else equal.

\section{The follow-up to Operation Pretense}

Operation Pretense generated vocal public condemnation of Mississippi's county boards of supervisors and led to calls for replacing the decentralized beat system of governance with a more centralized unit system. ${ }^{28}$ In August 1988, after months of debate about whether to force each county to switch from the beat system to the unit system or to allow voters to petition to have the beat-unit system issue placed on the November ballot, the Mississippi legislature passed a bill authorizing each county chose its system of governance. ${ }^{29}$ In addition, however, the bill mandated that all of the state's 82 counties adopt a centralized system for administering

\footnotetext{
${ }^{28}$ Under the unit system, many of the routine activities of county government, including purchasing, personnel policies, and inventory control and storage, are removed from the direct control of individual supervisors, who continue to be elected to represent geographically defined "beats." In carrying out their responsibilities with respect road construction and maintenance, supervisors serve primarily in a policymaking capacity, collectively establishing priorities by simple majority rule and then delegating authority for executing their decisions to a hired professional road manager who supervises the day-to-day activities of county road crews. Only two of Mississippi's 82 counties operated under the unit system before 1988 (see footnote 2).

${ }^{29}$ This special bill was necessary because Mississippi's constitution does not allow for voter initiative or referendum measures.
} 
purchasing, inventory control and storage, and personnel policies. In other words, the legislature's action meant that Mississippi's voters would vote only on the issue of centralized versus decentralized road districts.

Proponents of the unit system of county government, led by then-Governor Ray Mabus, who had served as the State Auditor of Mississippi while Operation Pretense was underway and based his successful campaign for the governor's mansion on his office's close cooperation with the FBI's undercover investigation, highlighted the cost savings that would follow from reducing wasteful duplication of capital and other resources due to multiple, independently supervised road districts. In expressing support for the unit system, U.S. Attorney Robert Whitwell argued that, "The state needs honest professionals running county government, not untrained road foremen and good ol' boys.... The county unit bill will help eliminate supervisors who abuse the system and line their pockets at the expense of taxpayers by removing supervisors from direct involvement in road building and maintenance." ${ }^{30}$

On the other hand, opponents of the unit system, spearheaded by the Mississippi Association of Supervisors (MAS), maintained that such efficiencies were largely based upon the untested assumptions that a centralized county government would exercise greater control over unethical and illegal behavior, allocate the county's resources public-spiritedly toward projects whose benefits were high relative to their costs, and, thus, promote more efficient provision of local public goods. ${ }^{31}$ The MAS contended that, by preventing direct communication between

\footnotetext{
${ }^{30}$ Clarion-Ledger (Jackson, Miss.), 26 October 1988, p. 1B.

${ }^{31}$ To our knowledge, only one empirical study comparing beat and unit system counties has ever been conducted. Published in August 1987, the study examined the experience of Neshoba County, whose supervisors voted unanimously on July 2, 1984, to switch from the beat to the unit system, a transition that was completed on September 1, 1986. A comparison of total county expenditures for personnel, utilities and contractual services, and materials for fiscal year 1985-86 (Mississippi's fiscal year runs from July 1 to June 30) with annualized data for the first three months of fiscal year 1986-87 showed that the unit system produced savings on the order of 38\%, or $\$ 533$ per county road mile (Crockett, 2003: 182-83). Ironically - or perhaps not - "three of the five Neshoba County
} 
elected supervisors and their constituents, the unit system would in fact do just the opposite, namely worsen road repair and maintenance services.

In the end, voters in 46 counties opted for the unit system and 36 counties chose to remain under the beat system. Karahan, Razzolini and Shughart (2002) provide an empirical analysis of the November 1988 election and its sequel, in November 1992, in which two unitsystem counties, Jones and Tate, voted to revert to the beat system. ${ }^{32}$ Importantly, Karahan et al. find no evidence that the outcomes of these two elections were influenced by revelations of public corruption: other things being the same, the voters in counties where one or more supervisors had been indicted under Operation Pretense were no more likely to vote in favor of switching to the unit system of governance than were the voters in non-corrupt counties. This result is consistent with the possibility alluded to earlier that voters were both aware of the existence of public corruption and condoned it as means by which supervisors could supplement their official salaries. ${ }^{33}$

\section{Summary and Conclusions}

This paper models public corruption at one of the lowest levels of governance. Previous studies have examined corrupt behavior largely on an international scale. Thanks to Operation Pretense, our dataset, by contrast, contains well-documented cases of corruption among approximately one-eighth of Mississippi's 410 elected county supervisors.

supervisors who had implemented the transition to the unit system were indicted by federal authorities and eventually pleaded guilty as a result of [Operation] Pretense" (ibid.: 111).

32 According to Crockett (2003: 297), Lincoln County also switched back to the beat system in early 2000.

${ }^{33}$ An anecdote recounted by a candidate for Lafayette County supervisor (see footnote 8) reinforces this interpretation. According to him, it was common knowledge before Operation Pretense began making headlines that supervisors took money under the table to supplement the pay they earned from performing what was then - and now - a part-time job. Voter indifference to revelations of government corruption is illustrated by a story from Pontotoc County. On the evening prior to the date on which one of that jurisdiction's five convicted supervisors was scheduled to report to federal prison, the members of his church threw a going-away party in his honor. 
At the micro level, we find evidence that governments tend to be more corrupt in rural, counties with more county miles, less densely populated counties, where voter-taxpayers are not well-educated. We do not find that high pay for public officials leads to less corruption, ceteris paribus. As a matter of fact, corruption is found to be more likely in counties where supervisors were compensated more generously. Some rethinking of the efficiency wage story for public officials thus seems to be in order, especially so in light of the evidence reported herein that, among the sample of Mississippi counties in which any governmental corruption was observed, fewer supervisors engaged in corruption where their salaries were higher, but those who did were penalized more heavily, suggesting that bribes were larger or demanded more frequently. On the other hand, competition among county supervisors for bribes is shown here to reduce the level, if not necessarily the prevalence, of thievery. 
Appendix. Number of supervisors indicted by county

\begin{tabular}{|l|c|}
\hline \multicolumn{1}{|c|}{ County } & Number of Corrupt Supervisors \\
\hline Pontotoc & 5 \\
\hline Hancock & 4 \\
\hline Attala & 3 \\
\hline Copiah & 3 \\
\hline Greene & 3 \\
\hline Leake & 3 \\
\hline Neshoba & 3 \\
\hline Newton & 3 \\
\hline Wayne & 3 \\
\hline Clarke & 2 \\
\hline Jasper & 2 \\
\hline Lamar & 2 \\
\hline Lauderdale & 2 \\
\hline Monroe & 2 \\
\hline Perry & 2 \\
\hline Rankin & 2 \\
\hline Claiborne & 1 \\
\hline Covington & 1 \\
\hline Harrison & 1 \\
\hline Jackson & 1 \\
\hline Lincoln & 1 \\
\hline Marion & 1 \\
\hline Panola & 1 \\
\hline Scott & 1 \\
\hline Smith & 1 \\
\hline Winston & 1 \\
\hline Total & $\mathbf{a}$ \\
\hline & \\
\hline
\end{tabular}

${ }^{a}$ Operation Pretense indictments were handed down against 57 of Mississippi's 410 county supervisors. The total shown here excludes one supervisor who was found mentally incompetent to stand trial (Perry County), one supervisor (Claiborne County) who was found not guilty of all charges, and a third (Newton County) who pled guilty but died while awaiting the final disposition of his case. 


\section{References}

Ades, A. and R. Di Tella (1999). "Rents, Competition, and Corruption," American Economic Review 89: 982-93.

Aidt, T. S. (2003). "Economic Analysis of Corruption: A Survey,” Economic Journal 113: 63252.

Allison, P. (1999). Logistic Regression Using the SAS ${ }^{\circledR}$ System: Theory and Application. Cary, NC: SAS Institute, Inc.

Atkinson, K. E., J. F. Couch and W. F. Shughart II (1992). "Ethics Laws and the Outside Earnings of Politicians: The Case of Alabama's 'Educator-Legislators',' Public Choice 73: $135-45$.

Bardhan, P. (1997). “Corruption and Development: A Review of Issues,” Journal of Economic Literature 35: 1320-46.

Basu, K., S. Bhattacharya and A. Mishra (1992). "Notes on Bribery and the Control of Corruption," Journal of Public Economics 48: 349-59.

Becker, G. S. (1968). “Crime and Punishment: An Economic Approach,” Journal of Political Economy 76: 169-217.

Becker, G. S. and G. J. Stigler (1974). "Law Enforcement, Malfeasance, and Compensation of Enforcers," Journal of Legal Studies 3: 1-18.

Besley, T. and J. McLaren (1993). "Taxes and Bribery: The Role of Wage Incentives," Economic Journal 103: 119-41.

Bhagwati, J. N. (1982). "Directly Unproductive, Profit-seeking (DUP) Activities,” Journal of Political Economy 90: 988-1002. 
Crockett, J. R. (2003). Operation Pretense: The FBI's Sting on County Corruption in Mississippi. Jackson: University Press of Mississippi.

Di Tella, R. and E. Schargrodsky (2003). "The Role of Wages and Auditing during a Crackdown on Corruption in the City of Buenos Aires," Journal of Law and Economics 16: 269-92.

Elliott, K. A. (Ed.) (1997). Corruption and the Global Economy. Washington, DC: Institute for International Economics.

Frechette, G. R. (2003). “A Panel Data Analysis of the Time-Varying Determinants of Corruption," unpublished manuscript, Harvard University.

Goel, R. K. and M. A. Nelson (1998). “Corruption and Government Size: A Disaggregated Analysis," Public Choice 97: 107-20.

Jain, A. K. (2001). “Corruption: A Survey,” Journal of Economic Surveys 15: 71-121.

Karahan, G. R., L. Razzolini and W. F. Shughart II (2002). “Centralized versus Decentralized Decision-Making in a County Government Setting," Economics of Governance 3: 10115.

Krueger, A. O. (1974). “The Political Economy of the Rent-Seeking Society,” American Economic Review 64: 291-303.

Mauro, P. (1997). “The Effects of Corruption on Growth, Investment, and Government Expenditure," in K. A. Elliot (Ed.), Corruption and the Global Economy, 83-107. Washington, DC: Institute for International Economics.

Mississippi State Highway Department (1982, 1993). Miles and Vehicle Miles of Travel in Mississippi by Functional Classification. Jackson, MS: Mississippi State Highway Department, Transportation Planning Division, in cooperation with U.S. Department of Transportation, Federal Highway Administration. 
Mookherjee, D. and I. P. L. Png (1995). “Corruptible Law Enforcers: How Should They be Compensated?," Economic Journal 105: 145-59.

Office of External Affairs, Division of Research (various years). Mississippi Statistical Abstract. Starkville, MS: Mississippi State University.

Olson, M. (1965). The Logic of Collective Action: Public Goods and the Theory of Groups. Cambridge: Harvard University Press.

Rose-Ackerman, S. (1978). Corruption: A Study in Political Economy. New York: Academic Press.

Rose-Ackerman, S. (1999). Corruption and Government: Causes, Consequences, and Reform. Cambridge: Cambridge University Press.

Schneider, F. and D. H. Enste (2000). "Shadow Economies: Size, Causes, and Consequences," Journal of Economic Literature 38: 77-114.

Shleifer, A. and R. W. Vishny (1993). "Corruption,” Quarterly Journal of Economics 108: 599_ 617.

Stigler, G. J. (1974). “A Theory of Oligopoly,” Journal of Political Economy 72: 44-61.

Tollison, R. D. (1982). “Rent Seeking: A Survey,” Kyklos 35: 575-602.

Treisman, D. (2000). "The Causes of Corruption: A Cross-National Study," Journal of Public Economics 76: 399-457.

Tullock, G. (1967). “The Welfare Costs of Tariffs, Monopolies, and Theft,” Western Economic Journal 9: 379-92.

Van Rijckeghem, C. and B. Weder (2001). "Bureaucratic Corruption and the Rate of Temptation: Do Wages in the Civil Service Affect Corruption, and by How Much?," Journal of Development Economics 65: 307-31. 
U.S. Department of Commerce, Bureau of Census (various years). County and City Data Book. Washington, DC: USGPO. 